\title{
Alternaria spp. implicated in a disease complex of onion leaf blight in the tropics ${ }^{1,2}$
}

\author{
Jessie Fernánde $z^{3}$, Lydia I. Rivera-Vargas ${ }^{4}$, Irma Cabrera-Asencio ${ }^{5}$ \\ and Sharon A. Cantrell ${ }^{6}$
}

J. Agric. Univ. P.R. 95(1-2):57-78 (2011)

\begin{abstract}
Alternaria isolates were collected from onion foliage at different stages of the plant life cycle. Incidence of Alternaria species in cultivars 'Mercedes' and 'Excalibur' was determined during two consecutive growing seasons in fields located in southern Puerto Rico. Leaves showing purple to brown sunken elliptical lesions with chlorotic halos were taken at random. Five leaf sections $(0.5 \mathrm{~cm})$ from each sample were superficially disinfested, transferred to culture media and incubated, and isolations were documented. Disease incidence ranged from 25 to $52 \%$ in 60 - to 100-day-old plants. An increase in Alternaria incidence was observed in response to high relative humidity in the fields. A total of 280 isolates were obtained, and 35 were selected for morphological, pathogenic and molecular characterization. A complex of five different Alternaria species is associated with onion leaf blight on the island. Alternaria destruens, A. tenuissima, A. palandui, A. allii and a group of small-spore Alternaria sp., belonging to a taxonomically undescribed group, were identified. Sixty-two percent of selected isolates belong to this group having an $\boldsymbol{A}$. arborescens intermediate sporulation pattern. Alternaria destruens and $A$. palandui have not been previously reported as associated with onions in the Caribbean or in the Western Hemisphere. Pathogenicity tests showed that $A$. allii, A. tenuissima and Alternaria sp. were pathogenic to onion foliage, with $A$. allii as the most virulent. Molecular characteristics of the isolates were determined by using the ITS of the rDNA gene. Phylogenetic relationships based on rDNA ITS sequences from Alternaria isolates and other Pleosporaceae distinguished three clades. The first clade
\end{abstract}

${ }^{1}$ Manuscript submitted to Editorial Board 3 June 2010.

${ }^{2}$ This research was supported by an USDA TSTAR-97 grant and the Agricultural Experiment Station, University of Puerto Rico. Thanks are expressed on behalf of the authors to Víctor González, Luis Collazo and Alberto Vélez; and to agroenterprises owned by Orlando Escalera and Marcos Morales. We would like to especially thank Dr. Emory G. Simmons from Crawfordsville, Indiana, a world authority on Alternaria's taxonomy, for his interest in examining our cultures and collaboration with the project.

${ }^{3}$ Former graduate student, Department of Crop Protection, University of Puerto RicoMayagüez Campus, Mayagüez, PR 00681

${ }^{4}$ Professor, Department of Crops and Agroenvironmental Sciences, P.O. Box 9000, University of Puerto Rico-Mayagüez Campus, Mayagüez, PR 00681. Corresponding author: E-mail address: lydiai.rivera@upr.edu.

${ }^{5}$ Professor, Department of Crops and Agroenvironmental Sciences, HC-04 Box 7115, Agricultural Experiment Station, Juana Díaz, PR 00795-9998

${ }^{6}$ Professor, Turabo University, Science and Technology, P.O. Box 3030, Gurabo, PR 00778. 
of large filiform-beaked spores included $A$. allii from this study, as well as isolates from the GenBank (A. porri, A. solani, A. macrospora, A. zinniae and A. sesamicola). These formed a monophyletic group, discrete from other members of the genus. The second clade included a diverse group of smallspore Alternaria: A. tenuissima, A. alternata, A. palandui, A. destruens and Alternaria sp.; the third clade included Stemphylium spp.

Key words: Alternaria, Allium cepa, rDNA ITS region, late blight of onion

\section{RESUMEN}

Alternaria spp. implicadas en el complejo de la enfermedad del tizón foliar de la cebolla en los trópicos

Se colectaron aislados de Alternaria del follaje de cebolla en diferentes etapas del ciclo de vida de la planta. Se determinó la incidencia de las especies en los cultivares Excalibur y Mercedes durante dos épocas consecutivas de crecimiento en predios localizados en el sur de Puerto Rico. Se colectaron hojas al azar que mostraban lesiones elípticas hundidas de coloración púrpura a marrón con halos cloróticos. Se desinfestaron superficialmente cinco secciones $(0.5 \mathrm{~cm})$ de las hojas por cada muestra, se transfirieron a medio de cultivo, se incubaron y se documentaron los aislamientos. La incidencia de la enfermedad fluctuó de 25 a $52 \%$ en plantas de 60 a 100 días de madurez. Se observó un aumento en la incidencia de Alternaria en respuesta al aumento en la humedad relativa en los predios. En total se obtuvieron $\mathbf{2 8 0}$ aislados, de los cuales 35 se seleccionaron para la caracterización morfológica, patogénica y molecular. Un complejo de cinco especies diferentes de Alternaria está asociado a la quemazón o tizón de la hoja de cebolla en la isla. Se identificó a $A$. destruens, $A$. tenuissima, A. palandui, $A$. allii y un grupo de Alternaria sp. de esporas pequeñas perteneciente a un grupo taxonómicamente no descrito. Sesenta y dos por ciento de los aislados seleccionados pertenecen a este grupo, caracterizado por el patrón de esporulación intermedio de A. arborescens. Alternaria destruens y A. palandui no han sido reportadas anteriormente asociadas a cebolla en el Caribe ni en el Hemisferio Occidental. Las pruebas de patogenicidad mostraron que A. allii, A. tenuissima y Alternaria sp., fueron patogénicas al follaje de cebolla, siendo $A$. allï la más virulenta. Se utilizó la región ITS del rADN para la caracterización molecular de los aislados. Las relaciones filogenéticas basadas en las secuencias de la región ITS del rADN de los aislados de Alternaria y otras Pleosporaceae distinguen tres grupos o clados. El primer clado de aislados con esporas grandes y puntas filiformes incluye a $A$. allii, aislados durante este estudio, así como secuencias de aislados obtenidos del GenBank (A. porri, $A$. solani, A. macrospora, A. zinniae y A. sesamicola). Estas especies forman un grupo monofilético separado de otros miembros del género. El segundo clado incluye un grupo diverso de Alternaria de esporas pequeñas: $A$. tenuissima, A. alternata, A. palandui, A. destruens y Alternaria sp.; y un tercer clado que incluye a Stemphylium spp.

Palabras clave: Alternaria, Allium cepa, región ITS del rADN, quemazón, tizón tardío de la cebolla

\section{INTRODUCTION}

Species of Alternaria are important pathogens that cause plant and post-harvest diseases. They can be potential fungal contaminants that 
produce toxic metabolites (i.e., mycotoxins), or saprophytes, present in the air and in soil litter (Andersen et al., 2002; Zur et al., 1999). As an important worldwide plant pathogen, Alternaria spp. causes purple leaf blotch or late blight of onions under warm and humid conditions (Everts and Lacy, 1990; Miller and Lacy, 1995). Characteristics of the disease are sunken elliptical lesions in older leaves varying in color from purple to brown with chlorotic halos and concentric rings (Nolla, 1927; Schwartz and Mohan, 1995). Alternaria porri (J. B. Ellis) Ciferri has been identified as the causal agent of purple blotch in garlic, leek and onion foliage around the world (Koike and Henderson, 1998; Schwartz and Mohan, 1995). Erroneously the name Alternaria porri has been used for any large-spore Alternaria that was found on members of the Alliaceae (Simmons, 2007). In fact, A. allii Nolla was first described in 1927 by J. A. B. Nolla from foliar lesions in onions cv. Bermuda grown in the northern region of Puerto Rico, but the name fell into disuse (Nolla, 1927; Simmons, 2007). Recently, other notable species with large long-beaked conidia affecting onions such as A. iranica Simmons \& Ghosta from Iran, and A. vanuatuensis Simmons \& Hill from Vanuatu in Oceania have been described (Simmons, 2007).

In the field, Alternaria lesions disrupt photosynthesis and reduce the final output of the onion bulb. In Colorado, $A$. porri, $A$. alternata (Fries) Keissler (synonymous with $A$. tenuis) and $A$. tenuissima (Nees $\&$ Nees:Fr.) Wiltshire, have been implicated in a disease complex of onion leaf blight causing purple and brownish foliar lesions (Skiles, 1953). Optimum field conditions for disease development occurred during long wet periods of high relative humidity $(\mathrm{RH}>90 \%)$ or dew deposition with continuous temperatures ranging from 20 to $25{ }^{\circ} \mathrm{C}$ (Everts and Lacy, 1990). During environmental conditions that favor pathogen sporulation and conidia germination, fungicide control is ineffective (Miller, 1983). Yield losses can range from 30 to $50 \%$ and up to $100 \%$ because of the rapid dissemination of the disease in the field (Schwartz, 1999).

During February and April 2000, field surveys conducted by personnel of the University of Puerto Rico (UPR) in onion fields located at Santa Isabel and Guánica, Puerto Rico, showed that up to $52 \%$ of foliar lesions in onions were caused by at least three different Alternaria species: A. tenuissima, A. alternata, and Alternaria sp. (Vélez et al., 2004; Vélez-Rodríguez and Rivera-Vargas, 2007). They were easily isolated from foliar lesions of onion and were pathogenic under laboratory and greenhouse conditions. Isolates evaluated caused ellipsoidal sunken brownish to purple lesions that eventually extended to the tip of the leaf (Vélez-Rodríguez and Rivera-Vargas, 2007). Tip blight was well de- 
veloped seven days after inoculation. Alternaria tenuissima produced ellipsoidal light brown lesions with a dark halo margin measuring 0.6 $\times 0.3 \mathrm{~cm}$, twelve days after inoculation. Profuse mycelial growth and sporulation were observed at the center of the lesions. Brownish to purple lesions were observed with $A$. alternata and with an Alternaria sp. that was not identified. Interestingly, $A$. porri and $A$. allii were not isolated during these studies. The inability to isolate $A$. allii was probably due to the poor or non-sporulation of this species isolates that make them impossible to identify morphologically; they were therefore classified as unknowns by the authors (Vélez et al., 2004).

Alternaria taxonomy is complex. Many species have been described, and a number of morphologically distinct groups, especially of smallspore-catenulate Alternaria, have been isolated as complexes from different host plants (Hong et al., 2006; Pryor and Michailides, 2002; Skiles, 1953; Simmons, 2007). An important limitation to traditional classification of the genera is the absence of sexual stages. Characterizing and determining the relative importance of each Alternaria species infesting onion, using traditional microscopic or morphological methods, is challenging. Traditional characterization, based on cultural characteristics, conidial morphology and ontogeny, is usually time consuming and difficult in the absence of reliable reference materials and expertise. Morphological criteria are affected by culture media, culture age and environmental cultural conditions (Rotem, 1994; Simmons, 1992). Pathogenicity tests to separate pathogenic from saprophytic species may also yield inconclusive results under different growing conditions and with different cultivars. Correct identification of species of Alternaria affecting onion in tropical conditions in the Caribbean Basin, particularly in Puerto Rico, may require the use of diverse strategies, such as morphological criteria and the use of molecular techniques. Analysis of random amplified polymorphic DNA-polymerase chain reaction (RAPD-PCR), PCR amplification and sequencing of the nuclear internal transcribed spacer (ITS) of the ribosomal DNA (rDNA) gene, and amplified fragment length polymorphism (AFLP) fingerprinting have complemented traditional taxonomy (Chou and Wu, 2002; Pérez-Martínez et al., 2004; Pryor and Michialides, 2002; van der Waals et al., 2004).

Few studies have been published on the characterization of species of Alternaria causing diseases of onions under tropical conditions. Our objectives were to determine the incidence of Alternaria at the different stages of the onion life cycle under field conditions in Puerto Rico; to characterize these species on the basis of morphology, pathogenicity and DNA sequence data; and to determine phylogenetic relationships among Alternaria isolates associated with onion foliage under tropical conditions. The results will help in understanding the relative impor- 
tance of the population diversity and dynamics of Alternaria as an onion pathogen under tropical conditions.

\section{MATERIALSAND METHODS}

\section{Incidence of Alternaria spp. in onion fields}

Alternaria spp. incidence in onion foliage was determined during two consecutive growing seasons: November 2003 to January 2004, and February to April 2004 at the municipalities of Santa Isabel and Juana Díaz in southern Puerto Rico. Onions lots were planted following technological package for onion production (UPR-Agricultural Experiment Station, 1999). Onions rows and lots were separated by cultivar. Lot sizes were approximately between 2.9 and 3.7 ha. Lots were located at road PR-1, Bo. Jauca, Sector Destino, at Santa Isabel, Puerto Rico, [(N17 $58^{\prime} 39.8^{\prime \prime} / \mathrm{W} 66^{\circ} 22^{\prime} 47.1^{\prime \prime}$ at $22 \mathrm{~m}$ above sea level (Map Datun, Puerto Rico) (GPS 12 XL, 12 channel, Garmin 1996-2000)]", and at the UPR-Agricultural Experiment Station, Road $510 \mathrm{~km} 3.0$ Sabana Llana, Juana Díaz, Puerto Rico [(N18 ${ }^{\circ} 01^{\prime} 39.1^{\prime \prime} / \mathrm{W} 66^{\circ} 31^{\prime} 33.2^{\prime \prime}$ at 34 m above sea level (Map Datun, Puerto Rico) (GPS 12 XL, 12 channel, Garmin 1996-2000)].

Samples were collected every 14 days from four different plots planted with cultivars Mercedes (Seminis®) or Excalibur (Sunseeds®). A systematic zig-zag sampling technique was used during the survey. Onion leaves were randomly collected from every eighth row for a total of 50 samples per lot. Incidence was determined by counting elliptical brownish to purple foliar lesions from the field sampled. Samples were placed inside plastic bags in an ice box and transported from the field to the Plant Pathology Laboratory on the University of Puerto Rico, Mayagüez Campus. Temperature, precipitation and relative humidity data were collected at a meteorological station located at UPR-Agricultural Experiment Station, Juana Díaz. Precipitation and temperature data were taken with Land Surface (N18 $\left.01^{\prime} 58.2^{\prime \prime} / \mathrm{W} 66^{\circ} 31^{\prime} 53.2^{\prime \prime}\right)$ and Weskler (N18 $\left.01.584 \mathrm{~W} 06631.531^{\prime}\right)$ instruments, respectively, of the National Climatic Data Center, United States Weather Bureau.

A correlation analysis $(\alpha=0.05)$ based on Alternaria spp. incidence (\%) was performed. Correlation coefficient was calculated by using Pearson's method and InfoStat/Student 2.0 from the National University of Córdoba.

${ }^{7}$ Company or trade names in this publication are used only to provide specific information. Mention of a company or trade name does not constitute a warranty of equipment or materials by the Agricultural Experiment Station of the University of Puerto Rico, nor is this mention a statement of preference over other equipment or materials. 


\section{Fungal isolates}

For fungal isolation, five sections $(0.5 \mathrm{~cm})$ from each leaf sample were superficially disinfested with $70 \%$ ethyl alcohol, followed by $0.05 \%$ sodium hypochlorite, then rinsed twice with de-ionized double distilled sterile water. Leaf sections were transferred to acidified (25\% lactic acid) potato dextrose agar (APDA) (Difco) amended with streptomycin (Sigma $\left.{ }^{\circ}\right)$. Petri plates $(60 \times 15 \mathrm{~mm})$ were incubated for seven days at $\pm 27^{\circ} \mathrm{C}$ under a 10 to $12 \mathrm{~h}$ cool-white fluorescent dark/light cycle for one week. Thirty-five Alternaria isolates were selected on the basis of colony appearance for further morphological characterization (Table 1). Morphological characterization was based upon criteria established by Simmons (1992) using single-spore colonies of Alternaria, transferred to potato-carrot agar (PCA) and V8 juice agar (V8). Sporulation pattern and conidium morphology were examined after five to seven days at $27^{\circ} \mathrm{C}$ for a $12-12 \mathrm{~h}$ dark-light regime. Colony characteristics were described from six different culture media: corn meal agar (CMA), Czapeck agar, dichloran rose bengal yeast extract sucrose agar (DRYES), oatmeal agar (OA), PCA and V-8 agar (V8A). Fungal cultures were stored on PCA plates at $4^{\circ} \mathrm{C}$ and in lyophilized at $-20^{\circ} \mathrm{C}$.

Morphotype isolates of various Alternaria 'species groups' were obtained from E.G. Simmons [Alternaria infectoria Simmons (EGS27193), A. alternata (EGS34-016), A. arborescens Simmons (EGS39-128), A. tenuissima (Nees \& T. Nees: Fr.) Wiltshire (EGS34-015), and A. porri (EGS48-147)]. Pleospora eturmiuna Simmons (teleomorph of Stemphylium eturmiunum) were used for reference comparisons.

\section{Pathogenicity tests}

Pathogenicity tests were conducted in vitro in the laboratory and under field conditions at the Juana Díaz Agricultural Experiment Station. Onion cultivars Mercedes (Seminis $\left.{ }^{\circledR}\right)$, Excalibur (Sunseeds®), and Candy (Petoseed@) were used as test plants. For the in vitro tests, asymptomatic leaves collected from 60- to 70-day-old plants were treated as before described for fungal isolation, and placed in sterile humid chambers on petri plates $(100 \times 15 \mathrm{~mm})$ inside plastic boxes $(91 \times 41 \times 15 \mathrm{~cm})$ under high humidity (i.e., 90 to $100 \%)$ at $25^{\circ}$ C. Plastic boxes were randomly placed on laboratory benches, and all treatments were repeated three times. Nineteen Alternaria spp. isolates grown on PCA for seven to ten days at $12 \mathrm{~h}$ daylight regime were used during the pathogenicity tests (Table 1). Conidial suspension was prepared by flooding the cultures with sterile di-ionized distilled water and rubbing the fungal colony with a sterile crystal rod. Conidia concentration was adjusted to $10^{5} \mathrm{CFU}$ 's $/ \mathrm{ml}$ by using a hemacytometer. Inoculations were made at the middle region of 
TABLE 1.-Alternaria spp. isolated from onion foliage of cus. Mercedes and Excalibur from two locations in southern Puerto Rico and their GenBank accession numbers used for phylogenetic studies.

\begin{tabular}{|c|c|c|c|c|}
\hline Isolate no. & Species group ${ }^{1}$ & Onion cultivar & Locality & $\begin{array}{c}\text { GenBank } \\
\text { Accession no }\end{array}$ \\
\hline Alt1 $* 2$ & Alternaria destruens & Mercedes & Santa Isabel & DQ323681 \\
\hline Alt2* & A. destruens & Excalibur & Santa Isabel & DQ323680 \\
\hline Alt3* & A. tenuissima & Excalibur & Santa Isabel & \\
\hline Alt4* & A. tenuissima & Mercedes & Juana Díaz & DQ323692 \\
\hline Alt5* & A. tenuissima & Excalibur & Santa Isabel & DQ323695 \\
\hline Alt6* & A. tenuissima & Excalibur & Santa Isabel & DQ323684 \\
\hline Alt7* & A. tenuissima & Excalibur & Santa Isabel & - \\
\hline Alt8* & A. palandui & Mercedes & Santa Isabel & DQ323686 \\
\hline Alt9* & A. palandui & Mercedes & Santa Isabel & DQ323702 \\
\hline Alt10* & A. palandui & Mercedes & Juana Díaz & DQ323682 \\
\hline Alt 11 & A. palandui & Excalibur & Santa Isabel & - \\
\hline Alt $12 *$ & A. palandui & Excalibur & Santa Isabel & - \\
\hline Alt 13 & A. palandui & Mercedes & Santa Isabel & - \\
\hline Alt14* & A. palandui & Excalibur & Juana Díaz & DQ323687 \\
\hline Alt15 & Alternaria sp. ** & Mercedes & Santa Isabel & - \\
\hline Alt16 & Alternaria sp. ** & Mercedes & Santa Isabel & DQ323688 \\
\hline Alt $17^{*}$ & Alternaria sp. ** & Mercedes & Santa Isabel & DQ323689 \\
\hline Alt18* & Alternaria sp. ** & Mercedes & Santa Isabel & DQ323690 \\
\hline Alt19 & Alternaria sp. ** & Mercedes & Santa Isabel & DQ323707 \\
\hline Alt20 & Alternaria sp. ** & Mercedes & Santa Isabel & DQ323701 \\
\hline Alt21 & Alternaria sp. ** & Mercedes & Santa Isabel & DQ323709 \\
\hline Alt22 & Alternaria sp. ** & Excalibur & Santa Isabel & DQ323694 \\
\hline Alt23* & Alternaria sp. ** & Mercedes & Santa Isabel & - \\
\hline Alt24 & Alternaria sp. ** & Excalibur & Santa Isabel & DQ323708 \\
\hline Alt25 & Alternaria sp. ** & Mercedes & Santa Isabel & - \\
\hline Alt26 & Alternaria sp. ** & Mercedes & Santa Isabel & DQ323685 \\
\hline Alt $27^{*}$ & Alternaria sp. ** & Excalibur & Santa Isabel & DQ323691 \\
\hline Alt28 & Alternaria sp. ** & Excalibur & Santa Isabel & DQ323696 \\
\hline Alt29 & Alternaria sp. ** & Excalibur & Santa Isabel & DQ323693 \\
\hline Alt30 & Alternaria sp. ** & Mercedes & Juana Díaz & DQ323703 \\
\hline Alt31* & Alternaria sp. ** & Excalibur & Santa Isabel & - \\
\hline Alt32 & Alternaria sp. ** & Mercedes & Santa Isabel & - \\
\hline Alt33 & Alternaria sp. ** & Excalibur & Santa Isabel & DQ323704 \\
\hline Alt34* & A. allii & Excalibur & Juana Díaz & DQ323705 \\
\hline Alt35* & A. allii & Mercedes & Juana Díaz & DQ323683 \\
\hline
\end{tabular}

${ }^{1}$ Species groups corroborated by Dr. Emory G. Simmons, Crawfordsville, IN. (pers. comm., 2004) on the basis of morphological characterization on Potato Carrot Agar.

$2 *=$ Isolates selected for pathogenicity tests; $* *=$ a taxonomically undescribed group of small-spore Alternaria spp. that has an A. arborescens intermediate sporulation pattern.

the leaves with or without wounding. Leaf tissue was wounded with a sterile dissecting needle and inoculum was applied with a sterile cotton swab soaked in the conidial suspension. Control plants were inoculated with sterile distilled water and handled as previously described. As for those Alternaria isolates that did not produce conidia on PCA, mycelial plugs $(4 \mathrm{~mm}$ ) were taken from the growing margin of the fungal colony ( 7 to $10 \mathrm{~d}$ old) and used for inoculation. Sterile 
PCA plugs were used as control. Pathogenicity tests were conducted twice. After inoculations, leaves were examined for disease symptoms and data of virulence were taken by measuring lesions in $\mathrm{cm}$. Pathogens were re-isolated to complete Koch postulates.

A field experiment was arranged in a randomized complete block design at the Juana Díaz Agricultural Experiment Station. Insecticides such as avermectin and cipermetrin were applied after the second and sixth weeks of planting, respectively. Variables and inoculation methods were as described before.

\section{Genomic DNA Extraction and Amplification of ITS region}

Total genomic DNA was extracted from selected Alternaria spp. single-spore isolates $(n=25)$ including four morphotypes provided by E.G. Simmons and Pleospora eturmiuna (Tables 2 and 3). Alternaria isolates were grown in $50 \mathrm{ml}$ of sterile potato dextrose broth (PDB, Difco). Cultures were placed on a rotary shaker at $120 \mathrm{rpm}$ and incubated in the dark at $27^{\circ} \mathrm{C}$ for seven days. Mycelia mats from cultures were harvested by vacuum filtration with a Buchner funnel and sterile filter paper (Fisher Scientific, P8) and transferred to sterile plastic tubes to be stored at $-20^{\circ} \mathrm{C}$. Genomic DNA was extracted from mycelium by using the FastDNA®Kit (Q-Biogene, Irvine, CA) according to the manufacturer's instructions in Fast PrepTM Bio 101 equipment (Thermo Electron Corporation Milford, MA). DNA samples were diluted in TE buffer ( $10 \mathrm{mM}$ Tris-HCL; $1 \mathrm{mM}$ EDTA) to a concentration of $25 \mathrm{ng} / \mu \mathrm{l}$ and stored at $-20^{\circ} \mathrm{C}$.

For sequence analysis, the nuclear rDNA gene ITS region, including ITS1, ITS2 and the $5.8 \mathrm{~S}$ ribosomal gene, was amplified by using polymerase chain reaction (PCR) with a thermocycler (Perkin Elmer, Model 2400, Wellesley, MA) and primers ITS1 and ITS4 (White et al., 1990). Polymerase chain reaction was performed in a total volume of $25 \mu \mathrm{l}$ containing $2.5 \mu \mathrm{l} 10 \mathrm{X}$ of TermoPol buffer (New England, BioLabs.), $200 \mu \mathrm{M}$ of each dNTP's (Roche®, USA), $1 \mu \mathrm{M}$ of each single

TABLE 2.-GenBank accession numbers of morphotypes of Alternaria spp. and Pleospora eturmiuna used for reference and comparison in phylogenetic studies.

\begin{tabular}{lll}
\hline Isolate no. & Species group & GenBank Accession no. \\
\hline Riv-St1 & Pleospora eturmiuna & DQ323706 \\
EGS27-1932 & A. infectoria & DQ323697 \\
EGS34-015 & A. tenuissima & DQ323698 \\
EGS34-016 & A. alternata & DQ323699 \\
EGS48-147 & A. porri & DQ323700 \\
\hline
\end{tabular}

\footnotetext{
${ }^{1}$ Pleospora eturmiuna (teleomorph of Stemphylium eturmiuna).

${ }^{2}$ Species groups obtained from Dr. Emory G. Simmons, Crawfordsville, IN. (pers. comm., 2004).
} 
TABLE 3.-Alternaria, Embellisima and Ulocladium sequences obtained from the GenBank and used for phylogenetic studies.

\begin{tabular}{lc}
\hline Species & GenBank Accession no. \\
\hline Alternaria alternata & DQ156341 \\
A. arborescens & AY154706 \\
A. destruens & AY278836 \\
A. longipes & AY154684 \\
A. macrospora & AY154689 \\
A. porri & AF229470 \\
A. sesamicola & AF314588 \\
A. solani & AY154716 \\
A. tenuissima & AY751455 \\
A. zinniae & AY154696 \\
Embellisima sp & AF212307 \\
Ulocladium sp. & AY943384 \\
Stemphylium botryosum & Y17068 \\
S. vesicarium & AF229484 \\
\hline
\end{tabular}

primer, $1 \mathrm{U} / \mu \mathrm{l}$ of Taq DNA polymerase (New England, BioLabs, MA) and $50 \mathrm{ng} / \mathrm{pl}$ of template DNA. Polymerase chain reaction conditions were as follows: $94^{\circ} \mathrm{C}$ for $4 \mathrm{~min}$, followed by 35 cycles of $94^{\circ} \mathrm{C}$ for 2 $\min , 55^{\circ} \mathrm{C}$ for $30 \mathrm{~s}$ and $72^{\circ} \mathrm{C}$ for $1 \mathrm{~min}$, with a final extension at $72^{\circ} \mathrm{C}$ for $4 \mathrm{~min}$. Two microliters of the PCR product was separated on $1.2 \%$ agarose gel (Fisher Scientific, New Jersey) prepared with 1X sodium bromide (SB) (Brody and Kern, 2004) and $4 \mu \mathrm{l}$ of ethidium bromide (1 $\mu g / 1 \mu l$, Sigma®, St. Louis, MO). Polymerase chain reaction products were visualized with a UV illuminator (Quantity One® 4.5 2003, BioRad Laboratory, Inc., Japan).

Polymerase chain reaction products were purified by using MinELute PCR Purification Kit (Qiagen $®$, Maryland) according to the manufacturer's instructions. The ITS region was sequenced by using forward primer ITS1 and reverse primer ITS4. The DNA was sequenced at the Molecular Resources Facilities of the New Jersey Medical School (http://www. umdnj.edu/mrfweb/).

Analysis of sequence data

Alternaria spp. sequences of the ITS region of the rDNA were edited and assembled by using Chromas Lite version 2.0 (www.technelysium. com.au) and aligned by ClustalX program version 1.83 . Distance analysis was performed by using the Phylo_win program (Genome Populations Interactions, University of Montpellier, France) with the Neighbor-Joining method. Kimura's two-parameter model of evolution was used and the number of bootstraps was 1,000 replicates. Similarity values between sequences were calculated by pairwise comparisons. Sequences from other species such as $A$. arborescens, $A$. longipes, $A$. macrospora, A. sesamicola, $A$. solani, $A$. zinniae and related genera 
(i.e., Embellisia sp., Stemphylium botryosum, S. vesicarium, Ulocladium sp.) were obtained from the GenBank database (Table 3).

\section{RESULTS}

Onion leaf blight was commonly observed in the southern region of Puerto Rico. Long elliptical purple and brown lesions with distinctive chlorotic halos were observed in the field (Figures 1A and 1B). Emerging Alternaria spp. conidiophores were frequently produced on infected tissue and easily observed under the dissecting microscope. Similar lesions were observed associated with herbicide and insect damage, especially leaf miners (Liriomyza sp.) (Figures 1C and 1D). Eventually, lesions caused the collapse or folding of the leaves affecting plant development and production (Figures $1 \mathrm{E}$ and $1 \mathrm{~F}$ ).

Alternaria's incidence

Alternaria spp. lesions were first observed between 18 to 31 days after planting (DAP) (Table 4). Incidence increased as plants of both cultivars developed. Higher incidence, $42 \%$ for Excalibur, $52 \%$ for Mercedes, occurred 60 to 102 days after planting (Table 4). During our studies, temperature ranged from 23.8 to $26.3^{\circ} \mathrm{C}$; precipitation was low, ranging from 0 to $0.29 \mathrm{~cm}$, and the relative humidity $(\mathrm{RH})$ ranged from 68 to $88 \%$ (Table 5). Disease incidence varied in response to RH. A positive correlation was observed between $\mathrm{RH}$ and Alternaria's incidence only in cultivar Mercedes $(r=0.7)$ at $\alpha=0.05$. Minimal fluctuations in temperature and precipitation occurred but correlation coefficients with incidence were not statistically significant (Table 5). Overall, no major differences were observed between onion cultivars in purple blotch incidence and colonies of Alternaria spp. recovered. Disease incidence in Juana Díaz was lower than in Santa Isabel (data not shown). At Juana Díaz, higher incidence was observed in 46- to 87-dayold plants ranging from 25 to $33 \%$ for the two cultivars evaluated.

\section{Alternaria species}

Two hundred and eighty Alternaria isolates associated with leaf blight of onion (cvs. Mercedes and Excalibur) were collected. Thirtyfive isolates were selected as representative groups for further characterization (Table 1). Based on morphology, four species groups were identified: Alternaria destruens, A. tenuissima, A. palandui (Ayyangar), and A. porri (Figure 2). Sixty-two percent of the selected isolates belong to a taxonomically undescribed group of small-spore Alternaria spp. having an $A$. arborescens intermediate sporulation pattern. Thus, a complex of five different Alternaria species is associated with onion leaf blight on the island. 

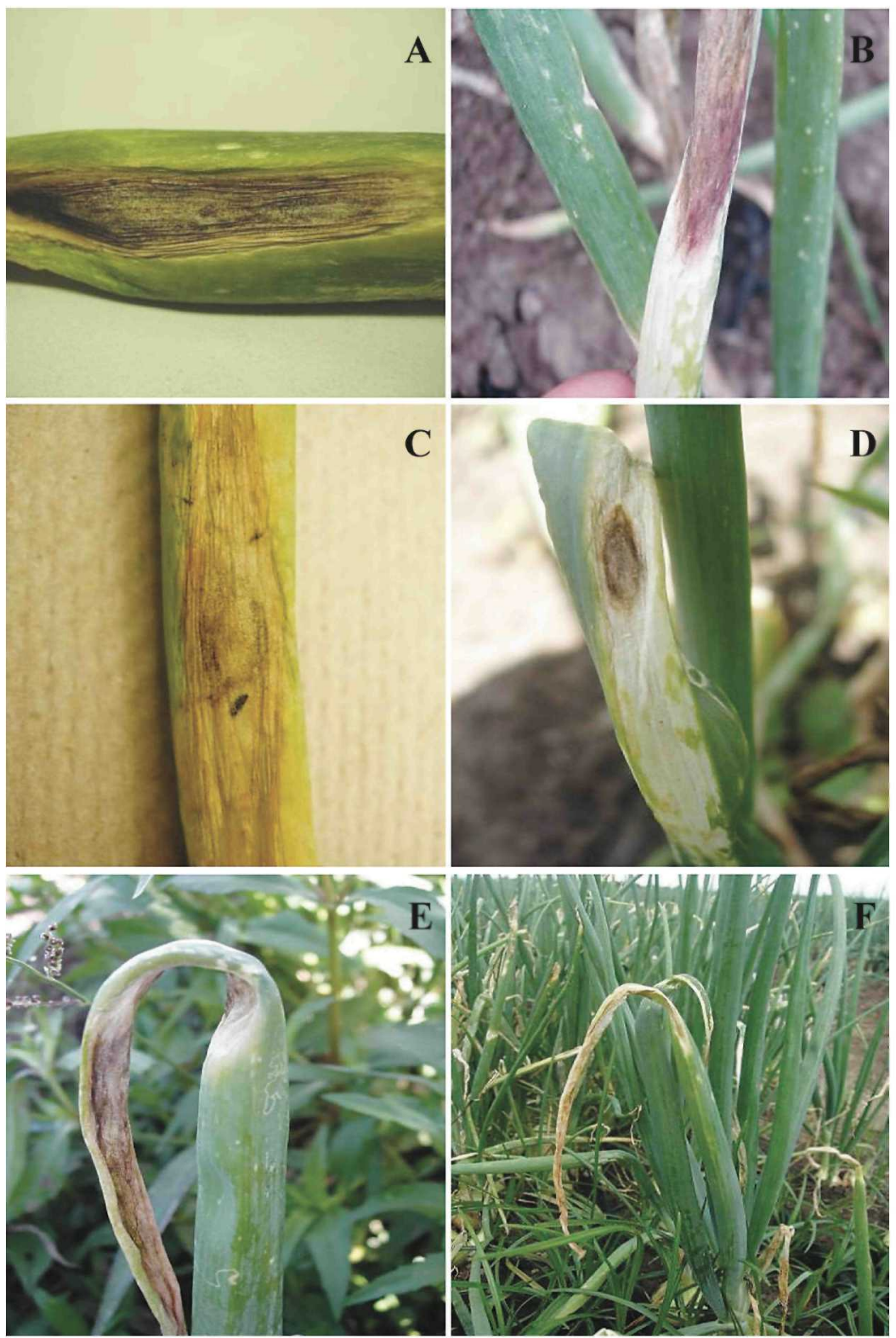

Figure 1. Common foliar lesions observed in onion in the southern region of Puerto Rico. A) Brown and B) purple lesions; Alternaria sp. growing on lesions from damage caused by C) leaf miners and D) herbicide; E) Collapse of the leaf caused by Alternaria spp.; and F) leaf blight in the field. 
TABLE 4.-Alternaria incidence (\%) during onion plant life cycle at commercial plots located at Santa Isabel, Puerto Rico.

\begin{tabular}{|c|c|c|c|c|}
\hline \multirow[b]{3}{*}{$\mathrm{DAP}^{1}$} & \multicolumn{4}{|c|}{ Onion Cultivars } \\
\hline & \multicolumn{2}{|c|}{ Mercedes } & \multicolumn{2}{|c|}{ Excalibur } \\
\hline & $\mathrm{C}^{2}$ & $\%$ & $\mathrm{C}$ & $\%$ \\
\hline $4-17$ & 0 & 0 & 0 & 0 \\
\hline $18-31$ & 14 & 28 & 4 & 8 \\
\hline $32-45$ & 7 & 14 & 14 & 28 \\
\hline $46-59$ & 2 & 4 & 0 & 0 \\
\hline $60-73$ & 23 & 46 & 24 & 48 \\
\hline $74-87$ & 14 & 28 & 24 & 48 \\
\hline $88-102$ & 26 & 52 & 21 & 42 \\
\hline $103-116$ & 8 & 16 & 3 & 6 \\
\hline
\end{tabular}

${ }^{1} \mathrm{DAP}=$ Days after planting, 2004.

${ }^{2} \mathrm{C}=$ Number of Alternaria colonies isolated from 50 samples.

Alternaria spp. colonies developed in six culture media were examined and their mycelial growth described (Table 6). Species were morphologically characterized on the basis of conidium size, number and type of septa, and catenulation (Table 7) (Figure 2). Isolates Alt34 and Alt35, belonging to the A. porri group, did not sporulate in culture media and were characterized on the basis of colony development, pathogenicity and DNA analysis. The narrow ellipsoid long-beaked conidia, typical of $A$. porri, were rarely observed (Figure 2E). These isolates produced an ochreous pigment on culture media similar to that which was described for A. allii by Nolla in 1927 (Figures $2 \mathrm{~F}$ and 3B). These two isolates, Alt34 and Alt35, will be referred to as $A$. allii from now on.

Isolates of $A$. destruens from Puerto Rico produced beakless amber conidia in simple chains of four to eight conidia characteristic of the

TABLE 5.-Temperature $\left({ }^{\circ} \mathrm{C}\right)$, relative humidity and precipitation during sampling period. Data taken at UPR-Agricultural Experiment Station, Juana Diaz, Puerto Rico. Average data from the second season.

\begin{tabular}{lccc}
\hline DAP & Temperature $\left({ }^{\circ} \mathrm{C}\right)$ & Relative humidity $(\%)$ & Precipitation $(\mathrm{cm})$ \\
\hline $4-17$ & 26.29 & 77.78 & 0 \\
$18-31$ & 25.71 & 76.73 & 0 \\
$32-45$ & 24.46 & 77.43 & 0.14 \\
$46-59$ & 24.45 & 68.39 & 0 \\
$60-73$ & 25.09 & 88.38 & 0 \\
$74-87$ & 25.44 & 74.08 & 0 \\
$88-100$ & 23.84 & 84.27 & 0.29 \\
$103-116$ & 26.13 & 81.13 & 0.29 \\
Average & 25.18 & 78.52 & 0.09 \\
\hline
\end{tabular}

${ }^{1}$ Days after planting during January to April, 2004. 
TABLE 6.-Colony descriptions of Alternaria spp. isolated from onion and grown in different culture media.

\begin{tabular}{|c|c|c|c|c|c|c|}
\hline \multirow{3}{*}{$\frac{\text { Alternaria spp. }}{\text { A. palandui }}$} & \multicolumn{6}{|c|}{ Culture media ${ }^{1}$} \\
\hline & V-8 & Czapeck & $\mathrm{OA}$ & DRYES & $\mathrm{PCA}$ & CMA \\
\hline & $\begin{array}{l}\text { Reddish } \\
\text { colony, } \\
\text { aerial } \\
\text { lium }\end{array}$ & $\begin{array}{l}\text { Dark olive green } \\
\text { colony, grey aeri- } \\
\text { al mycelium }\end{array}$ & $\begin{array}{l}\text { Light green to } \\
\text { grey colony, white } \\
\text { to cream aerial } \\
\text { mycelium }\end{array}$ & $\begin{array}{l}\text { Sandy cream col- } \\
\text { ony }\end{array}$ & $\begin{array}{l}\text { Dark olive green } \\
\text { colony, scarce } \\
\text { mycelium }\end{array}$ & $\begin{array}{l}\text { Dark brown colo- } \\
\text { ny, scarce myce- } \\
\text { lium }\end{array}$ \\
\hline A. destruens & $\begin{array}{l}\text { Dark brown } \\
\text { colony, no aerial } \\
\text { mycelium }\end{array}$ & $\begin{array}{l}\text { Reddish brown } \\
\text { colony, no aerial } \\
\text { mycelium }\end{array}$ & $\begin{array}{l}\text { Dark olive green } \\
\text { colony, no aerial } \\
\text { mycelium }\end{array}$ & $\begin{array}{l}\text { Cream to light yel- } \\
\text { low colony, pinkish } \\
\text { superficial myce- } \\
\text { lium }\end{array}$ & $\begin{array}{l}\text { Amber colony, } \\
\text { abundant amber } \\
\text { color conidia pro- } \\
\text { duced in media }\end{array}$ & $\begin{array}{l}\text { Dark brown colo- } \\
\text { ny, abundant light } \\
\text { brown conidia was } \\
\text { produced in media }\end{array}$ \\
\hline A. tenuissima & $\begin{array}{l}\text { Reddish brown } \\
\text { colony, cream } \\
\text { and brown } \\
\text { patches of aeri- } \\
\text { al mycelium }\end{array}$ & $\begin{array}{l}\text { Dark olive green } \\
\text { to brownish colo- } \\
\text { ny, pink to cream } \\
\text { center }\end{array}$ & $\begin{array}{l}\text { Dark olive green } \\
\text { colony }\end{array}$ & $\begin{array}{l}\text { Amber colony with } \\
\text { cream color areas }\end{array}$ & $\begin{array}{l}\text { Brown colony, } \\
\text { abundant } \\
\text { nidia }\end{array}$ & $\begin{array}{l}\text { Aerial mycelium } \\
\text { cream to brown in } \\
\text { color }\end{array}$ \\
\hline $\begin{array}{l}\text { A. tenuissima } \\
\text { Alt7 \& Alt8 }\end{array}$ & $\begin{array}{l}\text { Light brown to } \\
\text { greenish colony }\end{array}$ & $\begin{array}{l}\text { Light greenish } \\
\text { grey colony, dark } \\
\text { center }\end{array}$ & $\begin{array}{l}\text { Light green colo- } \\
\text { ny, scarce white } \\
\text { aerial mycelium }\end{array}$ & $\begin{array}{l}\text { Amber to yellow } \\
\text { colony, white mar- } \\
\text { gins }\end{array}$ & $\begin{array}{l}\text { Dark green colo- } \\
\text { ny with a darker } \\
\text { center, abundant } \\
\text { conidia }\end{array}$ & $\begin{array}{l}\text { White to cream } \\
\text { colony, scarce my- } \\
\text { celium }\end{array}$ \\
\hline Altemaria sp. & $\begin{array}{l}\text { Brown colony, } \\
\text { light grey aerial } \\
\text { mycelium }\end{array}$ & $\begin{array}{l}\text { Light grey with } \\
\text { darker center } \\
\text { colony }\end{array}$ & Dark grey colony & $\begin{array}{l}\text { Cream with white } \\
\text { margin colony }\end{array}$ & $\begin{array}{l}\text { Light brown } \\
\text { colony, abundant } \\
\text { conidia }\end{array}$ & $\begin{array}{l}\text { Cream with dark } \\
\text { center colony, } \\
\text { scarce mycelium }\end{array}$ \\
\hline A. allii & $\begin{array}{l}\text { Dark green to } \\
\text { reddish colony, } \\
\text { scarce pink aer- } \\
\text { ial mycelium, } \\
\text { ocherous pig- } \\
\text { ment on culture } \\
\text { media }\end{array}$ & $\begin{array}{l}\text { Dark olive green } \\
\text { with pink aerial } \\
\text { mycelium }\end{array}$ & $\begin{array}{l}\text { Light green colony } \\
\text { with ash grey my- } \\
\text { celium }\end{array}$ & $\begin{array}{l}\text { Dark green to yel- } \\
\text { low colony, con- } \\
\text { centric rings, light } \\
\text { green margins }\end{array}$ & $\begin{array}{l}\text { Scarce mycelium } \\
\text { light green }\end{array}$ & $\begin{array}{l}\text { Scarce mycelium } \\
\text { dark brown }\end{array}$ \\
\hline
\end{tabular}

${ }^{1} \mathrm{CMA}=$ corn meal agar; DRYES = dichloran rose bengal yeast extract sucrose agar; $\mathrm{OA}=$ oatmeal agar; $\mathrm{PCA}=$ potato carrot agar. 
TABLE 7.-Morphological characterization of Alternaria species group isolated from onion foliage.

\begin{tabular}{|c|c|c|c|c|c|c|c|}
\hline \multirow[b]{3}{*}{ Alternaria species group } & \multirow[b]{3}{*}{ Catenulation $^{1}$} & & & \multicolumn{4}{|c|}{ Conidial Size ${ }^{3}(\mu \mathrm{m})$} \\
\hline & & \multicolumn{2}{|c|}{ Num. Septa ${ }^{2}$} & \multicolumn{2}{|l|}{$\mathrm{L}$} & \multicolumn{2}{|l|}{ W } \\
\hline & & $\mathrm{T}$ & $\mathrm{L}-(\mathrm{O})$ & I & $\mathrm{A}$ & I & $A$ \\
\hline Alternaria destruens & $4-8$ & $3-6$ & $0-(2)$ & $(22-55)$ & 36 & $(10-15)$ & 11 \\
\hline A. tenuissima & $6-13$ & $4-8$ & $0-(2)$ & $(32-76)$ & 56 & $(10-18)$ & 13 \\
\hline A. palandui & $5-12$ & $3-8$ & $0-(2)$ & $(25-75)$ & 55 & $(8-12)$ & 10 \\
\hline Alternaria sp. ${ }^{4}$ & $4-10$ & $4-8$ & $0-(3)$ & $(35-68)$ & 47 & $(10-16)$ & 12 \\
\hline A. tenuissima & $6-10$ & $4-8$ & $0-(3)$ & $\begin{array}{l}(22-68) \\
\text { (2) }\end{array}$ & 55 & $(10-16)$ & 12 \\
\hline A. arborescens ${ }^{6}$ & $4-6$ & $2-4$ & $0-(1)$ & $(17-27)$ & 21 & $(8-11)$ & 10 \\
\hline A. allit ${ }^{7}$ & N/A & $\mathrm{N} / \mathrm{A}$ & & $\mathrm{N} / \mathrm{A}$ & & N/A & \\
\hline
\end{tabular}

${ }^{1}$ Number of conidia produced in chains (catenulation) on potato carrot agar.

${ }^{2}$ Number of transverse (T), longitudinal ( $L$ ) and oblique (O) septa.

${ }^{3}$ Measurements in micrometers $(\mu \mathrm{m}): \mathrm{L}=$ length, $\mathrm{W}=$ width, $\mathrm{I}=$ interval and $\mathrm{A}=$ Average.

${ }^{4}$ Alternaria sp. a taxonomically undescribed group (Simmons, pers. comm.).

${ }^{5}$ Pathogenic isolate.

${ }^{6}$ Isolate 39-128 (E. G. Simmons included as reference).

${ }^{7}$ Does not apply (N/A). These isolates did not sporulate in culture media.

species (Figure 2A). Conidial size ranged from 22 to $55 \mu \mathrm{m}$ long and 10 to $15 \mu \mathrm{m}$ wide with three to six transverse and two oblique septa (Table 7). Isolates of $A$. palandui from Puerto Rico produce narrow apical beak conidia, dark brown when mature with wall and septa contrastingly darker (Figure 2B). Conidial size ranged from 25 to $75 \mu \mathrm{m}$ long and 8 to $12 \mu \mathrm{m}$ wide with three to eight transverse and two oblique septa. Simple chains of five to 12 conidia were observed in PCA (Table 7).

Alternaria tenuissima produced dark brown verrucose conidia ranging in size from 22 to $68 \mu \mathrm{m}$ long and 10 to $16 \mu \mathrm{m}$ wide with four to eight transverse septa and three oblique septa in PCA. Alternaria tenuissima also showed conidial wall and septa that were contrastingly darker. Conidial chains of six to 10 spores were observed in PCA(Table 7).

A large number of isolates (62\%) from onion fields were included in a taxonomically undescribed group of small-spore Alternaria spp. having an A. arborescens intermediate sporulation pattern. Light brown ormamented (verrucose) conidia were short, ovoid to ellipsoid. Conidial size ranged from 35 to $68 \mu \mathrm{m}$ long and 10 to $16 \mu \mathrm{m}$ wide with four to eight transverse and three oblique septa. Conidial chains of four to 10 spores were observed as tufts in PCA (Table 7). Abundant sporulating hyphae were produced; these were long, and erect conidia production occurs aerially on the branching tips of the hyphae.

Other fungal species identified associated with onion foliar lesions were: Aspergillus niger, Curvularia sp., Fusarium sp., Glomerella 


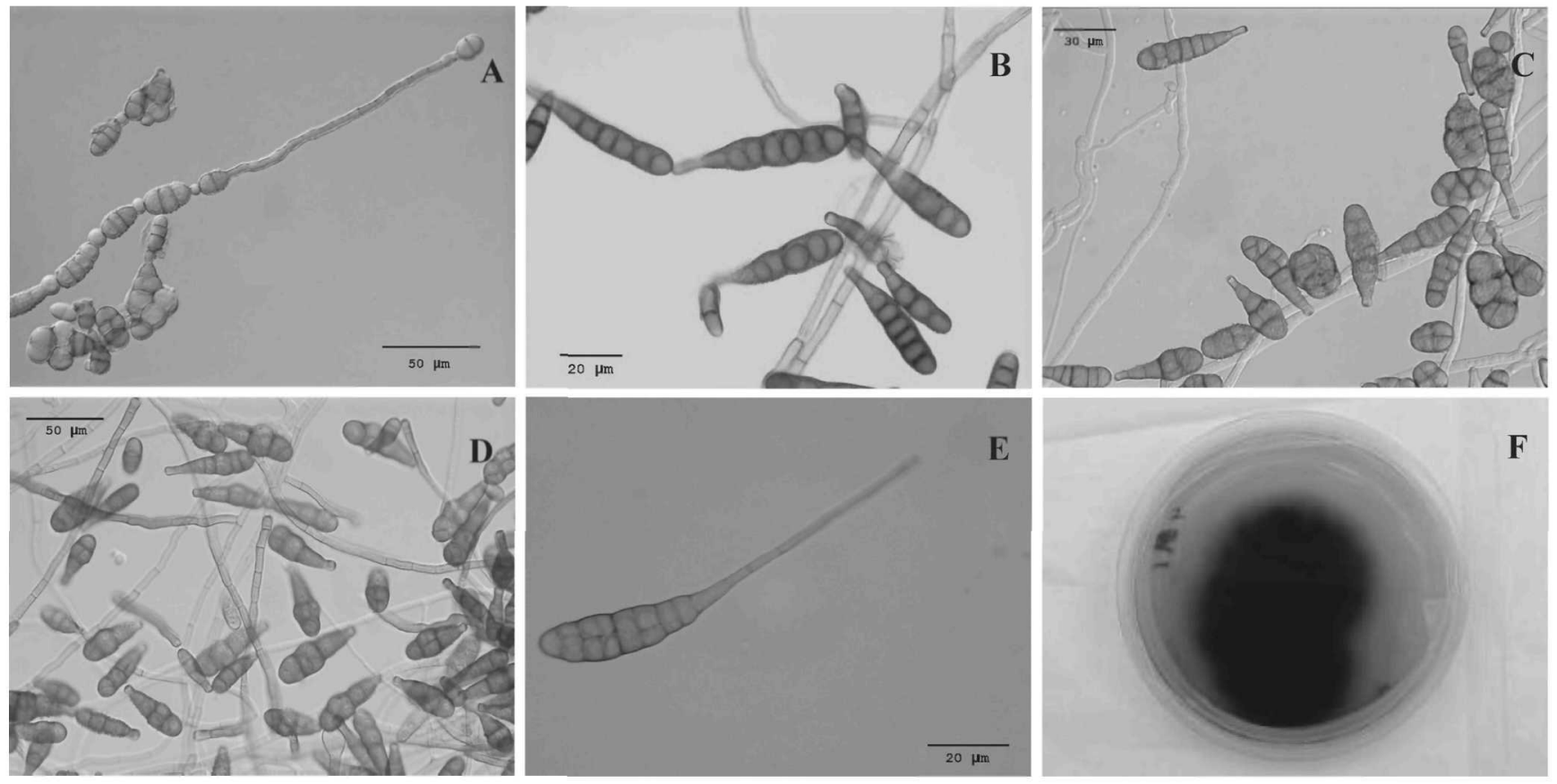

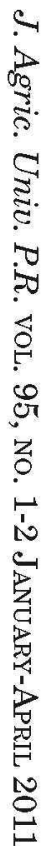

FIGURE 2. Conidia of A) A. destruens; B) A. palandui; C) Alternaria sp., an undescribed species with A. arborescens intermediate sporulation pattern; D) A. tenuissima; E) A. allii; and F) A. allii in culture media, observed ochreous pigment in PDA. 
cingulata (teleomorph of Colletotrichum gloeosporioides), Helminthosporium sp., Nigrospora sp., Penicillium sp., Pleospora eturmiuna Simm. (teleomorph of Stemphylium eturmiunum) and Verticillium sp. (Fernández and Rivera, 2006).

\section{Pathogenicity tests}

Out of 19 Alternaria isolates only five were pathogenic to onion foliage of cultivars Mercedes, Excalibur and Candy under laboratory (in vitro) and field conditions (Figure 3A; Table 8). These were two isolates of $A$. allii, two isolates belonging to $A$. tenuissima and one isolate of Alternaria sp. Isolates Alt34 and Alt35, belonging to A. allii, were the most virulent, causing larger lesions in wounded and unwounded leaves in both laboratory (in vitro) and field conditions in all cultivars evaluated. Lesion size ranged from 1.3 to $5.0 \mathrm{~cm}$ long and 0.9 to $1.2 \mathrm{~cm}$ wide. Typical elliptical foliar lesions were purple or dark brown with a chlorotic halo (Figure 3A). In the field, lesions were often observed extending from the tip of the leaf causing a brownish blight.

Isolates Alt6 and Alt7 belonging to the A. tenuissima species group developed foliar lesions only in wounded tissues on all cultivars evaluated. Lesions were smaller at 3.0 to $3.6 \mathrm{~cm}$ long and 0.6 to $0.8 \mathrm{~cm}$ wide. Alternaria tenuissima species group isolates were less virulent than $A$. allii, producing small light brown to reddish lesions which cause collapse of the leaves.

Alternaria sp. with an A. arborescens intermediate sporulation pattern, evaluated in this study, caused irregular lesions in wounded tissues of the three cultivars evaluated in the field. Elliptical brown to cream color lesions, ranging from 4.2 to $6.2 \mathrm{~cm}$ long and 0.7 to $1.0 \mathrm{~cm}$ wide were observed. Tissue collapsed at the center of the lesions.

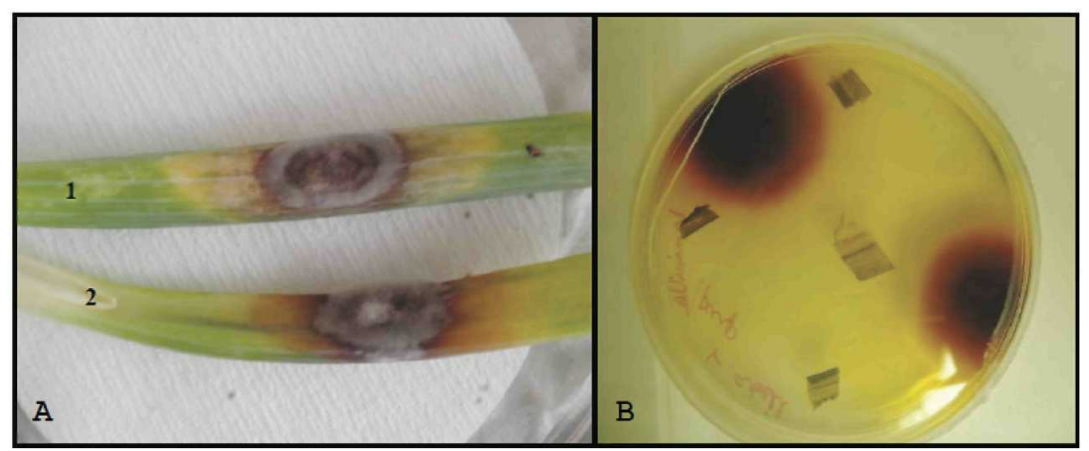

Figure 3. A) Purple foliar lesions developed during in vitro pathogenicity tests by isolate Alt34 (1) with wounding and (2) without wounding; B) Reisolation on culture media after pathogenicity tests to fulfill Koch postulates. Note ochreous pigment on culture media. 
TABLE 8.-In vitro and field pathogenicity tests conducted on three different onion cultivars, Mercedes, Excalibur, and Candy, with different Alternaria spp. isolates.

\begin{tabular}{|c|c|c|c|c|c|c|c|c|c|c|c|c|c|}
\hline \multirow[b]{3}{*}{ Isolates } & \multirow[b]{3}{*}{ Species Group } & \multicolumn{4}{|c|}{ Mercedes } & \multicolumn{4}{|c|}{ Excalibur } & \multicolumn{4}{|c|}{ Candy } \\
\hline & & \multicolumn{2}{|c|}{ Field } & \multicolumn{2}{|c|}{ In vitro } & \multicolumn{2}{|c|}{ Field } & \multicolumn{2}{|c|}{ In vitro } & \multicolumn{2}{|c|}{ Field } & \multicolumn{2}{|c|}{ In vitro } \\
\hline & & $W^{1}$ & UW & W & UW & $\mathrm{W}$ & UW & W & UW & W & UW & W & UW \\
\hline Alt6 & A. tenuissima & $t^{2}$ & - & - & $=$ & + & - & $=$ & $=$ & + & - & - & - \\
\hline Alt7 & A. tenuissima & + & - & - & - & + & - & - & - & + & - & - & - \\
\hline Alt27 & Alternaria sp. ${ }^{3}$ & + & - & - & - & + & - & $=$ & - & + & - & - & - \\
\hline Alt34 & A. allii & + & + & + & + & + & + & + & + & + & + & + & + \\
\hline Alt35 & A. allii & + & + & + & + & + & + & + & + & + & + & + & + \\
\hline
\end{tabular}

${ }^{1}$ Field pathogenicity tests using wounded (W) and unwounded= UW onion foliage tissue.

${ }^{2}$ Positive pathogenicity tests $(+)=$ leaf blight was observed on onion tissues; Negative pathogenicity tests $(-)=$ no symptoms were observed. ${ }^{3}$ Alternaria sp., a taxonomically undescribed group (Simmons, pers. comm.). 


\section{DNA analysis}

Sequence size of the nuclear internal transcribed spacer (ITS) of ribosomal DNA (rDNA) gene of different Alternaria spp. ranged from 530 to $600 \mathrm{bp}$. Sequence analysis of the region showed 98 to $100 \%$ homology among Alternaria isolates occurring in onions when compared to that of other sequences in the GenBank (Tables 2 and 3). Phylogenetic relationships based on sequences of the ITS region from Alternaria isolates and other Pleosporaceae (Ulocladium sp., Embellisima sp., and Stemphylium sp.) from the GenBank distinguished three distinctive clades (Figure 4). The first clade of large filiform-beaked spores included $A$.

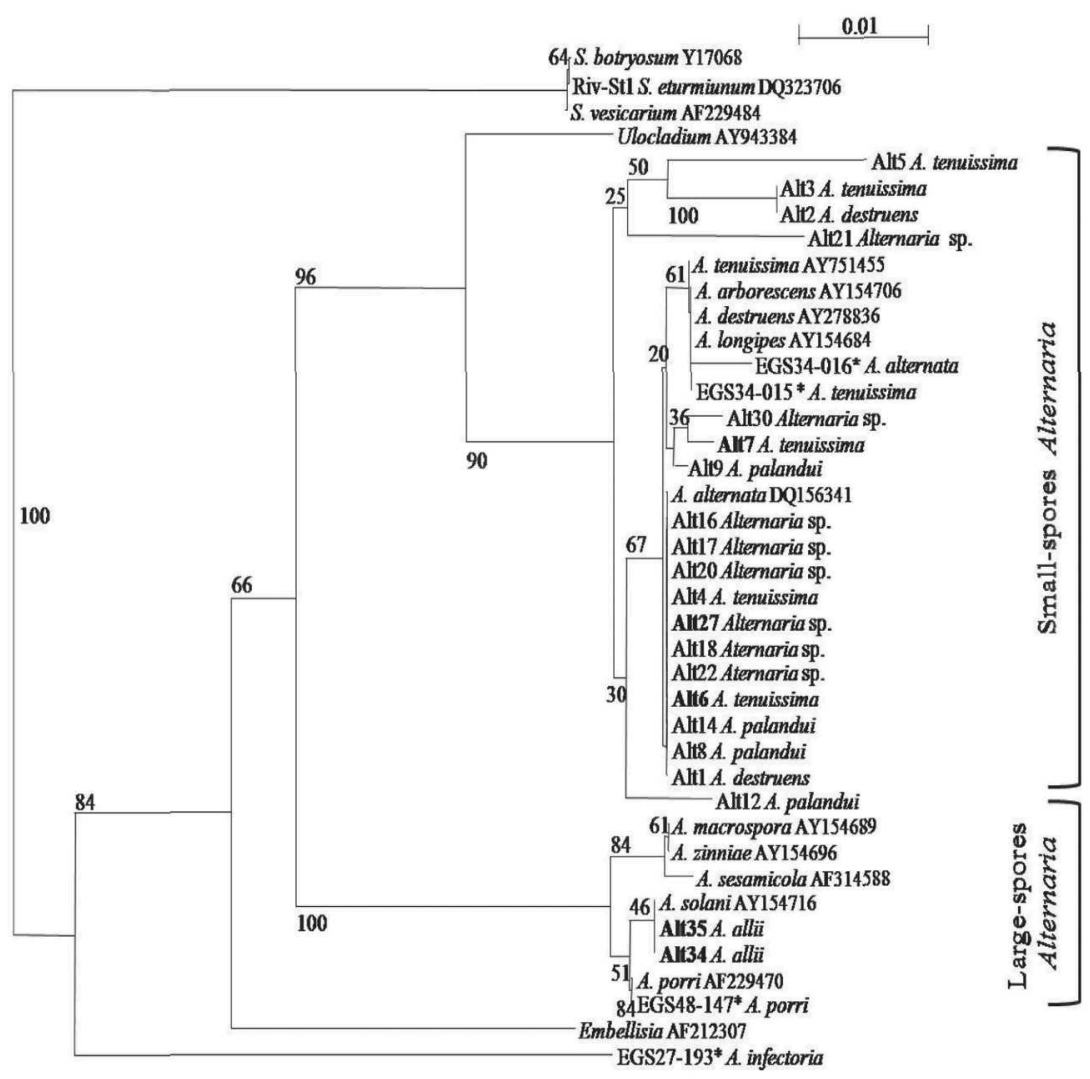

FIGURE 4. Phylogenetic tree obtained by Neighbor-Joining analysis of the nuclear ITS region of rDNA gene of Alternaria spp. and other Pleosporaceae. Kimura distance (parameter-2) was used with bootstraps of 1000 repetitions. * $=$ Morphotypes isolates from Emory G. Simmons collection; pathogenic isolates in bold; Alternaria sp. = a taxonomically undescribed group of small-spore Alternaria that has an A. arborescens' intermediate sporulation pattern. 
allii from this study, as well as isolates from the GenBank including A. porri, A. solani, A. macrospora, A. zinniae and A. sesamicola. These formed a monophyleic group, discrete from other members of the genus. The second clade included a diverse group of small-spore Alternaria, including $A$. tenuissima, A. alternata, $A$. palandui, $A$. destruens, and Alternaria spp. with an $A$. arborescens intermediate sporulation pattern; a third clade included Stemphylium spp. (Figure 4). Interestingly, Alt34 and Alt35, belonging to A. allii, were grouped along with $A$. solani and not with $A$. porri morphotype sequences obtained from the GenBank. Also the isolate of $A$. infectoria species-group segregated apart from the $A$. arborescens, $A$. tenuissima, and $A$. alternata. Alternaria sequences obtained during this study were deposited in the GenBank (Table 1).

\section{DISCUSSION}

Alternaria spp. incidence in onion increases as foliage matures, just before bulb development (Miller, 1983; Stavely and Slana, 1971). Similar findings were reported by Nolla in 1927 in onion fields located in the northern region of the island (Nolla, 1927). The highest RH occurred at maturity of the plant, a time which is the sensitive stage for Alternaria infection. Other authors reported that fungal infection has a higher incidence during periods of high relative humidity $(>90 \%)$ for more than $11 \mathrm{~h}$ or after morning dew at temperatures ranging from 20 to $25^{\circ} \mathrm{C}$ (Miller, 1975; Everts and Lacy, 1990).

Pathogenicity tests conducted in vitro and under field conditions using 19 Alternaria isolates showed that only five isolates belonging to three different Alternaria species groups were pathogenic to onions. These were $A$. allii, $A$. tenuissima, and Alternaria sp. (A. arborescens intermediate sporulation pattern). Alternaria tenuissima was reported pathogenic to onions in previous studies in Puerto Rico (Vélez-Rodríguez and Rivera-Vargas, 2007). Alternaria allii, developing lesions in unwounded tissues, was the most virulent species evaluated. Also, $A$. allii was consistently pathogenic in all trial conditions tested. Preliminary reports of these findings have been published elsewhere (Fernández et al., 2005; Fernández and Rivera, 2008).

Pathogenicity tests conducted with 14 isolates, belonging to $A$. destruens, A. palandui, A. tenuissima, and Alternaria sp. (A. arborescens intermediate sporulation pattern) species group, were negative. Small spore Alternaria spp., such as Alternaria destruens and A. palandui, have not been previously reported as associated with onions in the Caribbean or in the Western Hemisphere. Alternaria destruens was reported on a parasitic plant, Cuscuta gronovii, in Rochester, 
Massachusetts (Simmons, 1998). Cuscuta sp. was commonly observed growing near onion plants in fields in Puerto Rico. Thus, this data could explain the presence of $A$. destruens in onion fields. Alternaria palandui was first reported affecting onion foliage of cultivar Bellary in India (Ayyangar, 1928). This group of non-pathogenic Alternaria isolated from typical lesions in the field, were acting as saprophytes or secondary invaders after $A$. porri (or $A$. allii) infected the tissue. Interestingly, $A$. palandui was reported pathogenic to onions in India on cultivar 'Bellary', but onion cultivars commonly grown in Puerto Rico and tested during these studies apparently were resistant to this species (Ayyangar, 1928).

In Puerto Rico, brown and purple foliar lesions were common in the field. Even though A. porri is commonly known as purple blotch, other species have been reported associated with similar symptoms in onions. Among them are A. allii, A. alternata, A. iranica, A. palandui, A. tenuissima, $A$. tenuis and $A$. vanuatuensis (Ayyangar, 1928; Nolla, 1927; Skiles, 1953; Simmons, 2007; Vélez-Rodríguez and Rivera-Vargas, 2007). Alternaria was also found associated with foliar damage caused by leaf miners (Liriomyza sp.) and herbicide treatments. Isolates belonging to $A$. allii were the most virulent, penetrating tissue with and without wounding in all cultivars evaluated. Other species examined such as A. tenuissima and Alternaria sp. were none or only weakly pathogenic. Alternaria tenuissima and A. tenuis have been found associated only with wounded onion tissues (Skiles, 1953). In Puerto Rico, further studies on the relationship between insects and Alternaria spp. incidence in the field are needed. In particular, studies relating onion thrips damage to Alternaria spp. severity in the field are important. Recent reports of Frankliniella thrips species affecting onions may exacerbate Alternaria spp. severity in the field by allowing new sites for fungal penetration, especially species such as $A$. tenuissima and Alternaria sp., which require open wounds to cause infection (Feliciano et al., 2008). In fact, Thrips tabaci damage to onion foliage and its relationship to Alternaria spp. severity is well documented (McKenzie et al., 1993). Effective insect control could diminish Alternaria infection in the field.

Analysis of the rDNA ITS region of Alternaria spp. showed it to be highly conserved and did not distinguish it among small-spore $A l$ ternaria, thus confirming previous findings with Alternaria population associated with late blight of pistachios and citrus (Roberts et al., 2000; Pryor and Michailides, 2002). This region was inappropriate for taxonomic resolution of these species; however, it has value in discriminating among the small-spore vs. large-spore Alternaria. Isolate of $A$. infectoria species-group segregated apart from the $A$. arborescens, $A$. 
tenuissima, and A. alternata. Our results support previous findings with $A$. infectoria from pistachios (Pryor and Michailides, 2002). Alternaria allii were grouped with $A$. solani and not with $A$. porri morphotypes obtained from the GenBank. This piece of evidence in addition to the fact that these isolates produced an ochreous pigment on culture media, similar to what was described for $A$. allii by Nolla in 1927, make us believe that Alt34 and Alt35 are A. allii isolates. Future research should be focused on resolving Alternaria systematic by using other molecular techniques or biochemistry.

\section{LITERATURE CITED}

Andersen B., E. Kroger and R. G. Roberts, 2002. Chemical and morphological segregation of Alternaria arborescens, $A$. infectoria and $A$. tenuissima species groups. $M y$ col. Res. 106(2):170-182.

Ayyangar, C. R., 1928. A leaf spot and blight disease of onions caused by Alternaria palandui nov. sp. Agricultural Research Institute, Pusa. 79:1-14.

Brody, J. R. and S. E. Kern, 2004. Sodium boric acid: a Tris-Free, cooler conductive medium for DNA electrophoresis. Biotech. 36:214-216.

Chou, H. H. and W. S. Wu, 2002. Phylogenetic analysis of internal transcribed spacer regions of the genus Alternaria, and the significance of filament-beaked conidia. Mycol. Res. 106 (2):164-169.

Everts, K. L. and M. L. Lacy, 1990. The influence of dew duration, relative humidity, and leaf senescence on conidial formation and infection of onion by Alternaria porri. Phytopathology 80:1203-1207.

Feliciano, M., I. Cabrera-Asencio and L. I. Rivera-Vargas, 2008. Frankliniella occidentalis, F. schultzei and F. fusca (Thysanoptera: Thripidae) in Puerto Rico. J. Agric. Univ. P.R. 92 (1-2): 107-110.

Fernández, J., L. I. Rivera and I. Cabrera, 2005. Incidence and morphological characterization of Alternaria spp. occurring in onions in southern Puerto Rico. Phytopathology 96:S162.

Fernández, J. and L. I. Rivera, 2006. First report of leaf spot of onion caused by Pleospora eturmiuna in Puerto Rico. Phytopathology 96:S35.

Hong, S. G., M. Maccaroni, P. J. Figuli, A. Belisario and B. M. Pryor, 2006. Polyphasic classification of Alternaria isolated from hazelnut and walnut fruit in Europe. $M y$ col. Res. 104:1312-1321.

Koike, S. T. and D. H. Henderson, 1998. Purple Blotch, caused by Alternaria porri, on leek transplants in California. Plant Dis. 82(6):710.

McKenzie, C. L., B. Cartwright, M. E. Millar and J. V. Edelson, 1993. Injury to onions by Thrips tabaci (Thysanoptera: Thripidae) and its role in the development of purple blotch. Environ. Entomol. 22 (6):1266-1277.

Miller, M. E., 1975. Environmental factors associated with the spread of purple blotch of onions. Proc. American Phytopathological Society 2:35 (Abstr.).

Miller, M. E., 1983. Relationships between onion leaf age and susceptibility to Alternaria porri. Plant Dis. 67:284-286.

Miller, M. E. and M. L. Lacy, 1995. Purple blotch. In compendium of onion and garlic diseases.pp-23-24. APS Press, St Paul, MN.

Nolla, J. A. B., 1927. New Alternaria disease of onions (Allium cepa L.). Phytopathology $17: 115-132$. 
Pérez-Martínez, S., R. Snowdon and J. Pons-Kühnemann, 2004. Variability of Cuban and international populations of Alternaria solani from different hosts and localities: AFLP genetic analysis. European Journal of Plant Pathology 110: 399-409.

Pryor B. M. and T. J. Michailides, 2002. Morphological, pathogenic, and molecular characterization of Alternaria isolates associated with Alternaria late blight of pistachio. Phytopathology 92:406-416.

Roberts, R. G., S. T. Reymond and B. Andersen, 2000. RAPD fragment pattern analysis and morphological segregation of small-spored Alternaria species and species groups. Mycol. Res. 104 (2): 151-160.

Rotem, J., 1994. The Genus Alternaria: Biology, Epidemiology and Pathogenicity. APS Press, St. Paul, Minn. 326 pp.

Schwartz, H. F. and S. K. Mohan, 1995. Compendium of onion and garlic diseases. APS Press, St Paul, Minn. 54 pp.

Schwartz, H. F., 1999. Botrytis, downy mildew and purple blotch of onion. Crop Series, Diseases. Colorado State University Cooperative Extension. www.colostate.edu/ Depts/CoopExt

Simmons, E. G., 1992. Alternaria taxonomy: current status, view-point, challenge. In Alternaria: biology, plant disease and metabolites (J. Chelkowski \& A. Visconti, eds); pp. 1-35. Elsevier, Amsterdam.

Simmons, E. G. and R. G. Roberts, 1993. Alternaria themes and variations (73). Mycotaxon 48:109-140.

Simmons, E. G., 1998. Alternaria themes and variations (224-225). Mycotaxon 28:417427.

Simmons, E. G., 2007. Alternaria: An Identification Manual. CBS Biodiversity Series 6, Utrecht, the Netherlands. 775pp.

Skiles, R. L., 1953. Purple and brown blotch of onions. Phytopathology 43:409-412.

Stavely J. R. and L. J. Slana, 1971. Relation leaf age to the reaction of tobacco to Alternaria alternata. Phytopathology 61:73-78.

van der Waals, J. E., L. Korsten and B. Slippers, 2004. Genetic diversity among Alternaria solani isolates from potatoes in South Africa. Plant Dis. 88:959-964.

Vélez-Rodríguez, L. and L. I. Rivera-Vargas, 2007. Recent studies of fungal pathogens of onions in Puerto Rico. J. Agric. Univ. P.R. 91(1-2):31-45.

Vélez, L., L. I. Rivera, R. Rodríguez and I. Cabrera, 2004. Hongos asociados al cultivo de cebolla (Allium cepa L.) en la zona sur de Puerto Rico. J. Agric. Univ. P.R. 88(12):55-72.

White, T. J., T. Bruns, S. B. Lee and J. W. Taylor, 1990. Amplification and direct sequencing of fungal ribosomal RNA genes for phylogenetics. In: PCR protocols: A guide to methods and applications. M. A. Innis, D. H. Gelgard, J. J. Snisky and T. J. White (Eds.). pp. 315-322. Academic Press, N.Y.

Zur, G., E. M. Hallerman, R. Sharf and Y. Kashi, 1999. Development of a polymerase chain reaction-based assay for the detection of Alternaria fungal contamination in food products. J. Food Protection 62(10):1191-1197. 